spelaa; 2. Ursus spelaus; 3. Hyana spelaa; 4. Bos primigenius; 5. Hippopotamus major; 6. Cervus megaceros: making six out of the eight species assigned to Maccagnone.

These six identifications are simply imaginary; not one of the species, so far as I am aware, having been as yet mentioned on authority, as occurring in the Grotto of Maccagnone.

Such a wholesale manufacture of species, in a case of such gravity, requires no comment.

London, June 23, 1862.

Your obedient servant,

H. FALCONER.

\title{
Discovery of a Human Skeleton and other Remains in the bed of the River Soar, at Leicester.
}

On the western side of the town of Leicester there is an old bridge, known as the "Bow Bridge." It has recently been taken down for reconstruction; during the progress of the work the stream has been stopped, and a dam thrown across the channel north and south of the bridge, leaving the bed of the river dry. The upper surface was a black, muddy, alluvial deposit, but this being penetrated, the pure Drift gravel presented itself. This gravel lies immediately on the abraded surface of the Upper Keuper Sandstone, which here dips away under the town towards the Liassic hills on the eastern side. In excavating on the east side of the old bridge for the new foundations, and digging in the bed of the river, the workmen came upon ground in the Drift of a mixed character, gravel and silt. After digging out three feet of this, they came upon a human skeleton lying face upwards, the knees drawn towards the head. It was nearly entire, a few of the vertebræ and the smaller bones of the hands and feet only are wanting. Near this skeleton were found the skull of a horse, ox horns, and other bones.

The old bridge is of some antiquity, and is supposed to have been erected in the twelfth century. The road to which it leads is the Via Vicinalis of the old Roman town of Rate, and leads to the "Home War," another Roman road near Leicester. Over this bridge Richard the Third rode to the field of Bosworth, and his body is said to have been thrown over the bridge into the river by the multitude. Be this as it mav, the navvies and common people firmly believe this skeleton to be the remains of that monarch ; but as Richard"s body was "hacked to pieces," and his age at his death was about thirty-five, and as the bones bear no appearance of being "hacked," and the Iast molar being still in its socket, no weight can be given to such an impression. Certainly Richard the Third lad cut his "wisdom teeth."*

$23 r d$ June, 1862.

James Plant.

\footnotetext{
* These remains have been transmitted to us for inspection. It is a young, and secrningly not adult, woman's skeleton.--ED. GEOL.
} 